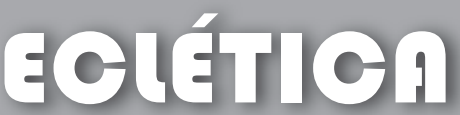 química
}

\section{CHEMICAL INDEXES CALCULATED FOR 8,11,13-TRIEN- ABIETANE DITERPENOIDS ISOLATED FROM SWARTZIA SPECIES}

\author{
A. F. Magalhães ${ }^{a *}$; A. M. G. A. Tozzi ${ }^{b}$; C. C. Santos ${ }^{a}$; E. G. Magalhães ${ }^{a}$. \\ ${ }^{a}$ University of Campinas, UNICAMP, Institute of Chemistry, P. O. Box 6154, 13083-970, Campinas, SP, Brazil \\ ${ }^{b}$ University of Campinas, UNICAMP, Institute of Biology, P. O. Box 6109, 13083-970, Campinas, SP, Brazil \\ ${ }^{a}$ Correspondence to: Aderbal F. Magalhães. \\ E-mail adress: aderbal@iqm.unicamp.br
}

\begin{abstract}
The disparity found in the molecular structures of compounds isolated from nine plants of the Swartzia genus indicates that the Swartzia species that furnished cassane diterpenoids and triterpenoidal saponins are more recent, since these metabolites have adopted the mevalonic acid route of formation, abandoning the shikimic acid/acetate route that produces the isoflavonoids found in the remaining species. Chemical indexes calculated from the molecular structure diversities of sixteen 8,11,13-trien-abietane diterpenoids isolated from Swartzia langsdorffii and $S$. arborescens indicate that $S$. arborescens is more recent than $S$. langsdorffii. The results suggest a more evolved position in Swartzia species of the section Possira.
\end{abstract}

Keywords: Leguminosae, Systematics of Swartzia genus, plant evolution, chemical index, chemotaxonomy.

\section{Introduction}

The genus Swartzia Schreb. belongs to tribe Swartzieae, subfamily Papilionoideae (Faboideae) of the Leguminosae (Fabaceae), and consists of about 180 species distributed in tropical America [1]. It was revised by Cowan [2], who recognized two sections, Swartzia sect. Possira (Aubl.) DC. and Swartzia sect. Swartzia, one subsection, and eight series.

Nevertheless, studies conducted after this review showed, directly or indirectly, the need of a revision of the infrageneric classification, due the artificiality of some series [3-10]. In fact, some of the Swartzia species are included in two distinct subsections or series and varieties of the same species have been placed in different series 11]. Cowan attempted to order the species in his monograph along putative phylogenetic lines, but his infrageneric groups were not intended to reflect common ancestry. Indeed, a systematic study of Swartzia, based on morphological and molecular characters, could provide an evolutionary basis to evaluate the infrageneric taxonomy of Cowan [2].

Recently, it was pointed out [11] that Swartzia should be retained without further division, despite its large number of species and considerable morphological diversity, because it was otherwise resolved as monophyletic, albeit with limited support. The present resolution of subclades of Swartzia should be used as a basis for revising the highly artificial infrageneric classification of Cowan [2].

Additionally, an updated monograph of the entire genus has taxonomic and phylogenetic significance because of the position of Swartzieae in the Papilionoideae classification. Molecular data strongly suggest that Swartzieae sens. strict. should be redefined to include only the genera 
Swartzia, Bobgunnia, Bocoa, Candolleodendron, that, instead of isoflavonoids [16-20], furnish terTrischidium, Cyathostegia, and Ateleia $[1,12,13]$. penoids.

Cladistic analyses showed the group of

Myrospermum, Myroxylon and Myrocarpus of Sophoreae to be associated with the Aldinoid clade of the Swartzieae and closely to Swartzieae sens. strict. [12]. The reclassification of Swartzieae sens. strict., and realignment of the remaining swartzioid genera in other tribes, needs to be corroborated by further evidence $[1,13]$.

On the other hand, evolutionary changes in plants can also be evaluated through the chemical structures of the special metabolites found in them, based on the disparity (related to the biogenetic route) and the diversity of their molecular structures [14]. The methodology is very attractive because it does not imply knowledge of the complete biogenetic route of metabolites and has already indicated evolutionary tendencies for the Swartzia species that produce isoflavonoids [15]. In this paper, the methodology is used to suggest evolutionary directions for two Swartzia species

\section{Methodology}

Disparity Evaluation- The disparity of metabolites reported in Swartzia genera were evaluated by comparing their chemical structures since, according to Gotlieb's methodology [14], dispaity in the maspalites indicas an lites indicates an evolutionary move and occurs by the replacement of compounds generated from the shikimic acid/acetate biogenetic route by compounds generated from the acetated route (or mevalonic acid route)

Accordingly, the species were separated into two groups, those that furnished special metabolites originating from the shikimic acid/aceate route - the isolavonids, and those th is nic acid e terpenoids (Table 1 ).

Table 1. Correlation between chemical data reported for Swartzia studied phytochemically and botanic classification (Cowan 1967), phylogeny reported in the current literature (Torke \& Schaal 2008).

\begin{tabular}{ccccccc}
\hline & Cowan 1967 & $\begin{array}{c}\text { Araujo 2007; } \\
\text { Torke \& } \\
\text { Schaal 2008 }\end{array}$ & $\begin{array}{c}\text { Braz Filho et al. } \\
\text { 1980; Osawa et } \\
\text { al. 1992; Dubois } \\
\text { et al. 1995, 1996 }\end{array}$ & $\begin{array}{c}\text { Magalhães et al. } \\
\text { 2005; Orphelin } \\
\text { et al. 1996 }\end{array}$ & $\begin{array}{c}\text { Borel et al. } \\
\text { 1987; Abdel- } \\
\text { Kader et al. } \\
\text { 2000; Magalhães } \\
\text { et al. 2003 }\end{array}$ \\
\hline Species & Section & Series & Clade & Isoflavonoids & Diterpenoids & Saponins \\
\hline S. ulei & Swartzia & Benthamianae & & + & & \\
S. laevicarpa & Swartzia & Benthamianae & benthamioid & + & & + \\
S. leiocalycina & Swartzia & Recurvae & recurvoid & + & & + \\
S. polyphylla & Swartzia & Orthostyleae & orthostyloid & + & & + \\
S. schomburgkii & Swartzia & Orthostyleae & orthostyloid & & & + \\
S. apetala & Swartzia & Tounateae & tournateoid & + & & + \\
S. langsdorffii & Swartzia & Recurvae & acutifolioid & & + & + \\
S. arborescens & Possira & Possira & possiroid & & + & + \\
S. simplex & Possira & Possira / Unifoliolatae & possiroid & & & + \\
\hline
\end{tabular}

Diversity Evaluation- For contextualization and better visualization, the biodiversity observed for ten 8,11,13-trien-abietane diterpenoids isolated from S. langsdorffi, A, B, and 1-4 [21], including a pair of epimers, 5-8 [22] is explained through a series of methylation and oxidation reactions rationalized using a proposed biogenetic route (Fig. 2).

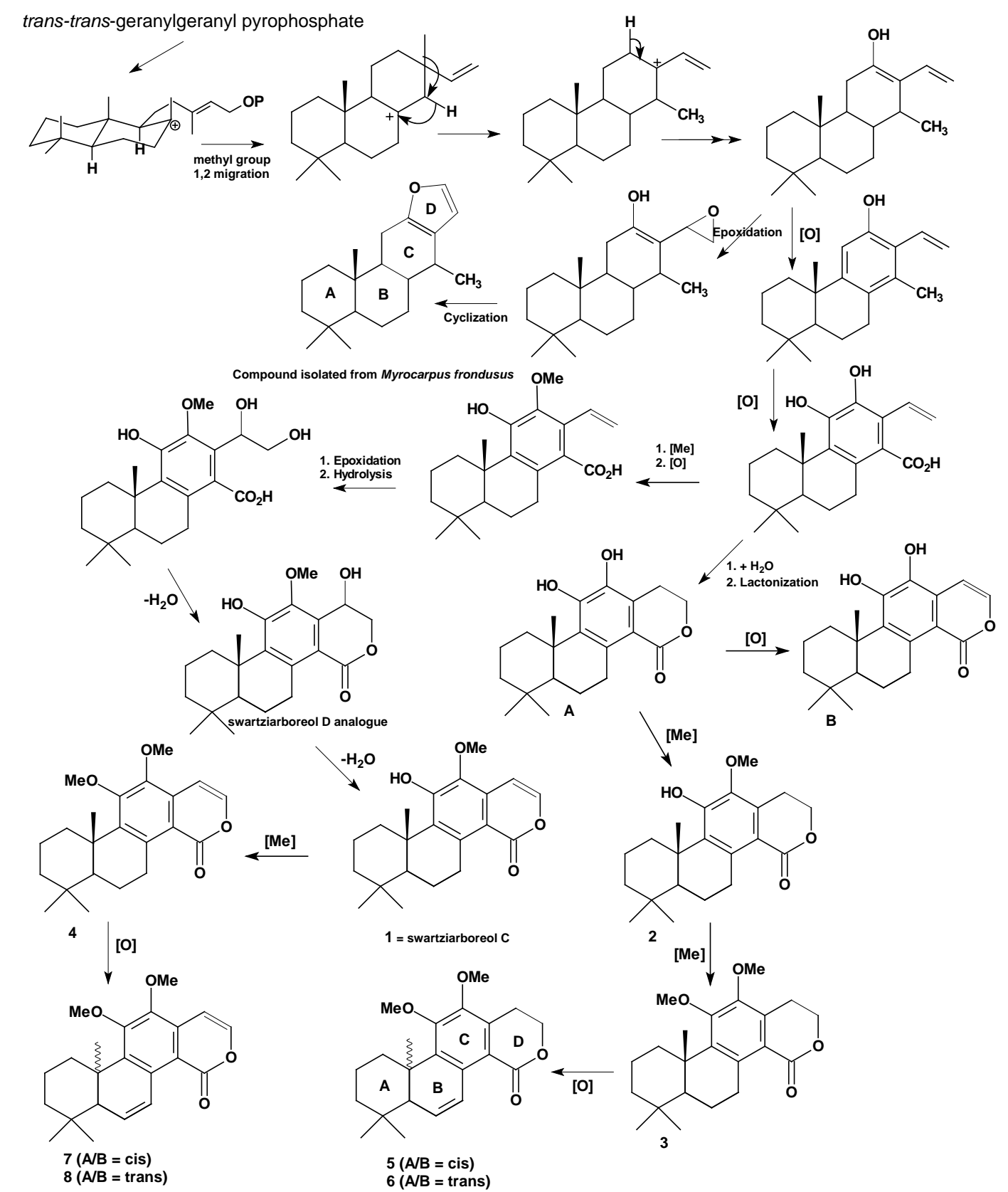

Figure 2. Biogenetic proposal rationalized for 8,11,13-trien-abietane diterpenoids isolated and identified from the native Brazilian tree Swartzia langsdorffi Raddii (Magalhães et al. 2005; Santos et al. 2007). 
The indexes $\mathrm{EA}_{\mathrm{O}}$ and $\mathrm{EA}_{\mathrm{E}}$ are found by cal-

The initial part of proposed route is very similar to that reported for the C-12 methoxy deininol [23] including a 1,2-methy si migration. However, the shift now propose siccurs between $\mathrm{C}-13$ and $\mathrm{C}-14$, and not between $\mathrm{C}-13$ and $\mathrm{C}-15$, and is reinforced by the detection of C-14 methylated 8,11,13-trien-abietane compounds in the species Myrocarpus frondosus [24], a species of the Sophoreae tribe, which is closely related to Swartzieae sens. strict.

Some cyclization processes are proposed leading to the compounds that were isolated from Swartzia species and from the species Myrocarpus frondosus. The metabolites carbon skeletal difference is in ring $\mathrm{D}$, as, in case of the metabolites furnished by $M$. frondosus, ring D would be formed by an oxidative cyclization reaction between C-16 and C-12, allowed by the absence of the protective C-12 methoxy group of swartziarboreols. In the case of swartziarboreols, however, oxidative steps would occur before a final cyclization reaction between $\mathrm{C}-16$ and $\mathrm{C}-17$ that would give rise to the isocoumarin ring $\mathrm{D}$. Then, the other compounds would be generated by a series of oxidative and methylation processes.

However, when Gottlieb's chemical index methodology is applied, a knowledge of such biogenetic pathways of special metabolites is not necessary since the evolutionary evaluation is made by means of two chemical indexes, the oxidative evolutive advance index, $\mathrm{EA}_{\mathrm{o}}$, and the skeleton complexity evolutive advance index, $\mathrm{EA}_{\mathrm{E}}$, of each plant species. culating the averages: $\mathrm{EA}_{\mathrm{O}}=(\Sigma \mathrm{O}) / \mathrm{N}$ and $\mathrm{EA}_{\mathrm{E}}=$ $(\Sigma E) / N$, where the value $\mathrm{N}$ refers to the number of metabolite occurrences, and the $\mathrm{O}$ and $\mathrm{E}$ oxidative degree of the molecular structures $(\mathrm{O})$ and the carbon skeleton specialization (E) of each metabolite.

The oxidative degree indexes $(\mathrm{O})$ were calculated by the equation, $\mathrm{O}=(\mathrm{x}-\mathrm{h}) / \mathrm{n}$, where the letters $\mathrm{n}, \mathrm{h}$ and $\mathrm{x}$ refer, respectively, to the total number of carbon atoms (n), the number of $\mathrm{C}-\mathrm{H}$ bonds (h) and the number of C-heteroatom bonds (x) of the terpenoid skeleton, while the carbon skeleton specialization indexes (E) were calcuted by compaing the Cabon (E) were colcu-

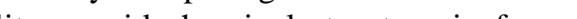
政 carbon skeleton of a hypothetic connon precursor (compound A; Fig. 1), by using the equation: $\mathrm{E}=(\mathrm{q}+\mathrm{f}+\mathrm{c}+\mathrm{u}) / \mathrm{n}$, where the letters $\mathrm{n}, \mathrm{q}, \mathrm{f}$ $c$, and $u$, represent, respectively, the total number of carbon atoms (n), the number of $\mathrm{C}-\mathrm{C}$ bonds broken (q), the number of C-C bonds formed (f), the number of rings formed with a heteroatom, (c), and the number of additional carbon atoms (u). Table 2 shows the $\mathrm{O}$ and $\mathrm{E}$ values found for . (u). Ta 2 shows the $O$ a same calculations were applied to the five diterpe. Fing re ). Finally, the oxidative advance index, $\mathrm{EA}_{\mathrm{O}}$, and the skeleton specialization advance index, $\mathrm{EA}_{\mathrm{E}}$ of each species are displayed in Table 4.

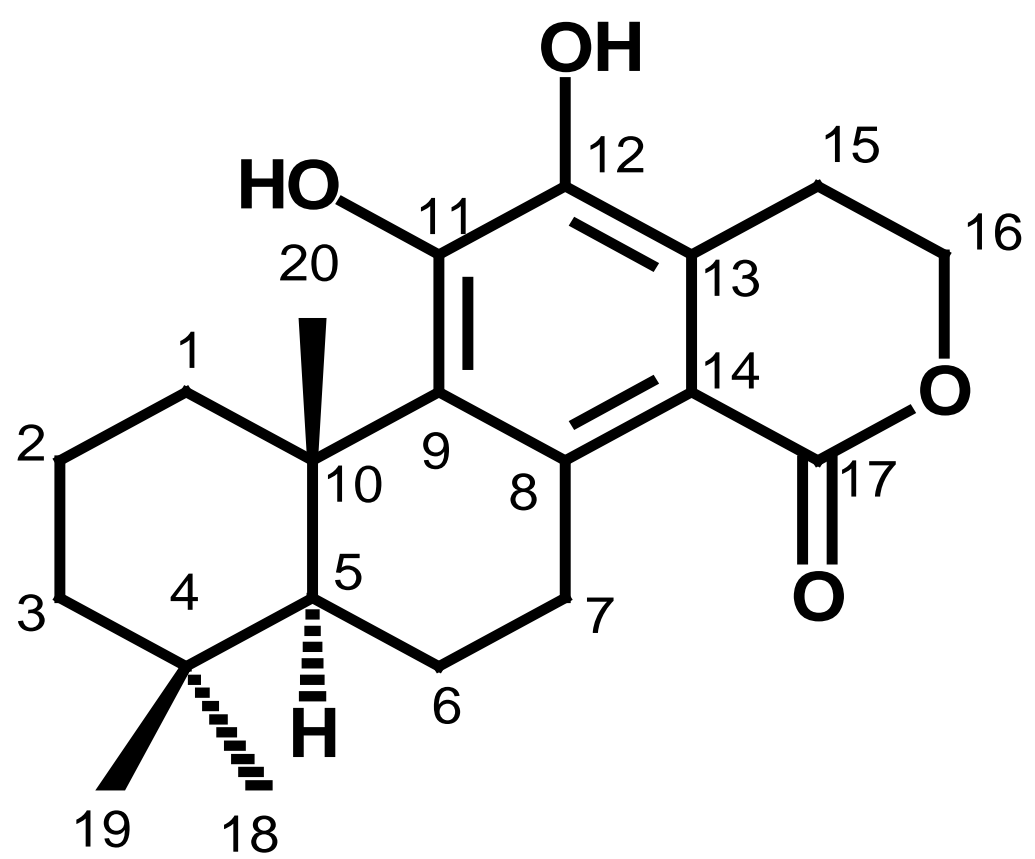

$A=$ common biogenetic precursor

Figure 1. Hypothetic common precursor which has been used to calculate skeleton complexity evolutive advance (EA) values for all swartziarboreols identified.

Table 2. Oxidative evolutive index values $(\mathrm{O})$, calculated for swartziarboreols isolated and identified in the extracts of S. langsdorffii (Magalhães et al. 2005; Santos et al. 2007).

\begin{tabular}{ccc}
\hline Compound & $\mathrm{O}^{*}$ & $\mathrm{E}^{* *}$ \\
\hline $\mathrm{A}$ & -0.90 & 0.00 \\
$\mathrm{~B}$ & -0.80 & 0.00 \\
1 & -0.86 & 0.00 \\
2 & -0.95 & 0.00 \\
3 & -0.91 & 0.00 \\
4 & -1.00 & 0.00 \\
5 & -1.00 & 0.00 \\
6 & -1.00 & 0.00 \\
7 & -0.91 & 0.00 \\
8 & -0.91 & 0.00 \\
\hline
\end{tabular}

$\mathrm{O}=\mathrm{x}-\mathrm{h} / \mathrm{n}$, where the letters refer, respectively, to the total carbon atoms (n), the $\mathrm{C}-\mathrm{H}$ bonds (h) and the C-heteroatom bonds (x) of the diterpenoid skeleton. ${ }^{* *} \mathrm{E}=$ Carbon skeleton specialization chemical index. 
Table 3. Oxidative evolutive index values $(0)$, calculated for the swartziarboreols A-E isolated and identified in the extracts of S.arborescens (Orphelin et al. 1996).

\begin{tabular}{ccc}
\hline Compound & $\mathrm{O}^{*}$ & $\mathrm{E}^{* *}$ \\
\hline swartziarboreol A & -0.62 & 0.00 \\
swartziarboreol B & -0.52 & 0.00 \\
swartziarboreol C & -0.71 & 0.00 \\
swartziarboreol D & -0.57 & 0.00 \\
swartziarboreol E & -0.57 & 0.00 \\
\hline
\end{tabular}

$\mathrm{O}=\mathrm{x}-\mathrm{h} / \mathrm{n}$, where the letters, refer, respectively, to the total carbon atoms (n), the C-H bonds (h) and he C-heteroatom bonds (x) of the diterpenoid skeleton. ${ }^{* *} \mathrm{E}=$ Carbon skeleton specialization chemical index.

Table 4. Values for oxidative evolutive advance and skeleton complexity evolutive advance, $\mathrm{EA}_{\mathrm{o}}$ and $\mathrm{EA}_{\mathrm{f}}$ calculated using the chemical index values found for the metabolites identified in the species S. langsdorffii and S. arborescens.

\begin{tabular}{ccc}
\hline Species & $\mathrm{EA}_{\mathrm{o}}{ }^{\mathrm{a}}$ & $\mathrm{EA}_{\mathrm{E}}{ }^{\mathrm{b}}$ \\
\hline S. langsdorffii & -0.94 & 0.00 \\
S. arborescens & -0.60 & 0.00 \\
\hline
\end{tabular}

$\mathrm{EA}_{\mathrm{o}}=\Sigma \mathrm{O} / \mathrm{n}{ }^{\mathrm{b}} \mathrm{EA} \mathrm{E}_{\mathrm{E}}=\Sigma \mathrm{E} / \mathrm{n} ; \mathrm{n}=$ metabolite occurrences.

\section{Results and Discussion}

Disparity Evaluation- Comparing the chemical structures of metabolites reported for Swartzia species (Table 1) it is possible to observe two groups characterized by the presence of isoflavonoids or terpenoids. Phytochemically stuied Swartzia specie (S. arborescens [25] S. simplex [26], S. schomburgki [27] and S. I], s. simplex [26], S. schomburgkii [27] and S. langsdorffii $[21,22,28]$ ) are more recent concerning the evolutionary aspects, since their metabolites were generated by the mevalonic acid route while the remaining species produced isoflavonoids that are formed by the shikimic acid/ acetate route.

Considering the clades obtained by Torke \& Schaal [12], the presence of these substances could be used, in addition to other data, to define he Swartzia clades: possiroid and acuifolioid cla-

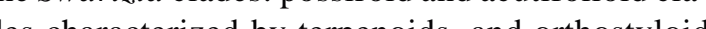
(estoid and benthamioid clades characterized by flavonoids (Table 1). In this sense, the systematic position of $S$. schomburgkii is doubtful, appearing with $58 \%$ maximum parsimony bootstrap support in a

combined chloroplast and nuclear sequences tree [12, Fig. 3]. In the trees obtained in separate searches of combined chloroplast sequence data and ITS sequences, S. schomburgkii and S. polyphylla remain in distinct clades [12, Fig. 1 and 2]. If the absence of diterpenoids in S. simplex would be confirmed, this would point out the applicability of subcategories in Possira classification.

Diversity Evaluation- The second evaluation was made by analysis of the diversity of he chemical structures of fifteen $8,11,13$-trienabietane diternenoids identified from the species S. arborescens and S. langsdorffi.

Different from isoflavonoid chemical index calculations, the chemical indexes for terpenoids, as mentioned above, is evaluated by the oxidative degree $(\mathrm{O})$ and by the carbon skeleton specialization (E) of their molecular structures. Table 2 shows the values of the chemical indexes obtained for $S$. langsdorffii metabolites. The same rationafiz. langs lifir me dization and kind of calculations led to the values borescens. borescens.
Since the carbon skeleton is the same for all the isolated swartziarboreols, the carbon skeleton specialization index (E) is zero for all of them, and the value of $\mathrm{EA}_{\mathrm{E}}=\Sigma \mathrm{E} / \mathrm{N}$ is also zero. The differences between meta The dofferes only to the oxidation indexes (O) calculated for each metabolite (Tables 2 and 3). Finally, Table 4 shows the $E A_{O}$ and $E A_{E}$ values found for each species, and indicate that, according to the chemical index methodology, S. arborescens is a more recent evolutionarily species than $S$. langsdorffii.

\section{Conclusions}

When considering chemical index methodology for taxonomic problem elucidation, the idea is to show a relationship between the plant evolutionary order found by the use of chemical indexes and the plant evolutionary order ateady

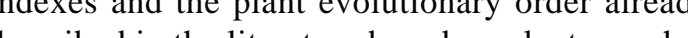
described in the literature based on plant morpho-

The use of the chemical index methodology demonstrates that molecular structure differences observed for the metabolites isolated from the two species that produce 8,11,13-trien-abietan diterpenoids, the native Brazilian tree Swartzia langsdorffi Raddii, included in the series Recurvae of Swartzia sect. Swartzia, and S. arborescen (Aubl.) Pittier (Swartzia sect. Possira), are related oxidative processes and indicated an evolutioto oxidative processes and indicate

Based on morphological data of S. langsdorffii, such as pattern venation, slender, axillary and shorter than leaf raceme, calyx shape, and androecium characteristics, and given the presence of terpenoids and terpenoidal saponins, we observe that this species is related to $S$. arborescen and to S. simplex, both pertaining to the section Possira.

Then, even though the aromatic diterpenoids found in S. langsdorffii were very similar to those isolated from $S$. arborescens, the chemical index values obtained for the two species allow suggesting that $S$. arborescens is evolutionarily more recent than $S$. langsdorffii. Those results corroborate the Cowan [2] evolutive line.
The Torke \& Schaal's molecular phylogeny of the neotropical species of Swartzia [12] identifies 11 nonoverlapping clades, few of which correspond exactly to previously published taxa [2]. The grouping of the clades orthostyloid axa and, as mentioned above, is chacterized by isoflavonoids. Thus, the pre, is chacterized by isoclades pusioid the presence of terpenoids in the evolutionary novelty.

A weighted cluster analysis based on wood anatomical characters, which shows seven distinct groups within the Brazilian species of Swartzia [29], add data to this recent cladistic analysis and can be correlated with our results. The authors pointed out some similarity of their wood groups with Cowan's [2] classification. Altough the species, which were studied phytochenis are not enough, the results can be dic ene useful to indicate phyllogenetic and taxonomic relationships in Swartzia. The correlation of chemical data and data reported by Angyalossy-Alfonso \& Miller [29] suggest an evolutionary tendency from group 4 (where are the species of orthostyloid and benthamioid clades) to group 5 (where S. arborescens is included). In this sense, for example, the multiseriate rays ved from the exclusively uniseriate rays.

Considering the presence of metabolites as one discriminating character for Swartzia sect. Swartzia, it seems that there are two subgroups: the orthostyloid clade characterized by isoflavonoids not containing a tetracyclic ring system and benthamioid, recurvoid and tournateoid clades characterized by the occurrence of pterocarpenoi-

Finally, our analysis compares favourably to some clades within cladistic analysis using molecular data of Torke \& Schaal [12]. The two main clades within Swartzia that were recovere by Torke $\&$ Schaal, the most interior node including most species and nine of the 11 supported subclades of Swartzia and other with orthostyloid and benthamioid clades, also finds support from the phytochemical data shown in this paper. 


\section{Acknowledgements}

The authors are grateful to the Instituto Agronômico de Campinas (IAC), Monjolinho, Fazenda Santa Elisa, SP, Brazil, for plant acquisition, to the Fundação de Amparo à Pesquisa do Estado de São Paulo (FAPESP), SP, Brazil, for financial support and to CAPES, Brazil, for a scholarship awarded to C. C. Santos, as well as to Dr Carol Collins for critical reading and English revision.

Resumo: A análise das estruturas moleculares dos compostos isolados de nove plantas do gênero Swartzia mostrou que, na produção de metabólitos especiais, algumas plantas abandonaram a rota do ácido shikimic/acetato e adotaram a rota do ácido mevalônico. Esta mudança é fator indicativo de que essas espécies são evolutivamente mais recentes. Já a diversidade de estruturas moleculares de swarziaboreols, idenificados en S. arborescens e S. longsdorfii, permitiuatibuir a cad a de swatziarboreols, identicados en $S$. arborescens e S. langsdorffi, permitiu atribuir a cada uma dessas espécies inn indice quínico, mostrando que os de S. arborescens são mais recentes do que os de $S$. langsdorffii. Os resultados sugerem que as espécies da seção Possira devam ocupar uma posição derivada em Swartzia.

Palavras-chave: Leguminosas, Sistematica do gênero Swartzia, evolução de plantas, índices químicos, quimiotaxonomia.

\section{References}

[1] H. Ireland, Tribe Swartzieae in Legumes of the World (Lewis, G., B. Schrire, B. MacKinder, and M. Lock, eds.) Royal Botanic Gardens, Kew, 2005, p. 215.

[2] R. S. Cowan. Swartzia (Leguminosae, Caesalpinioide Swartzieae). Fl. Neotrop. Monogr. (1) (1967)108. Hafner Publishing, New York.

[3] R.C. Baneby, Ann. MO. Bot. Gard. 78 (1991) 177.

[4] R.C. Barneby, Brittonia 44(2) (1992) 224

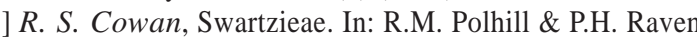
(eds), Advances in Legume Systematics, Royal Botanic Gardens, Kew, 1981, vol. 1, p. 209.

(7) J. S. Kowan, B J W W (3) (1985) 291

[7] V. Mand 1.

[9] V. F. Mansano, S. C. Tucker, A. M. G. de A. Tozzi, Am. J. Bot. 89 (2002) 1553

Rudas, Novon 4(2) (1994) 165

Aot. 29(2) (2004) 358

[12] B. M. Torke, B. A. Schaal, Am. J. Bot. 95(10) (2008) 1270.

[13] G. Lewis, B. Schrire, B. MacKinder, M. Lock (eds.). [14] O. R., Gottlieb, M. A. Kaplan, M. R. de M. B. Borin. Sistemas Qúmicos Gerais in Biodiversidade: Un Enfoque Químico-Biológico, ed. Universidade Federal do Rio de Janeiro, Rio de Janeiro, 1996, p. 65.
[15] A. F. Magalhães, A.M.G.A. Tozzi, C.C. Santos, E.G. Magalhães, Eclet. Quim. 31(2) (2006) 13.

161M. F. Ar Biológica de Swartzia apetala var. glabra. Tese e Avaliaçãa Centro de Ciencias e Tecnologia Campos dos Goytacazes, pesquisa/DetalheObrärm. do?select action=\&co bra =117032] acessed Jan 2009 [17] R. Braz Filho, M.P.L. Den Phytochemistry 19 (1980) 2003.

[18] K. Osawa, H.Yasuda, T.Maruyama, H.Morita , K. 19] J. L.Dubois, A. T. Sneden, J. Nat. Prod. 58(4) (1995) 629. 20] J. L.Dubois, A. T. Sneden, J. Nat. Prod. 59(9) (1996) 902. Magalhães, J. Nat. Prod., 68(8) (2005) 1290.

[22] C. C. Santos, E. G. Magalhães, A. F. Magalhães, Phytochem. Anal. 18(6) (2007) 484.

23] Y. Tomita, M. Annaka Y. Ikeshiro, J. Chem. Soc., Chem. Commun. (1989) 108.

24] M. A. F. Perez, Diterpenos de Myrocarpus frondosus biológica. Tese de Mestrado. Universidade Estadual de Campinas (Unicamp), Campinas, SP, Brazil, 2005. URL [http://biq.iqm.unicamp.br/arquivos/teses/ficha65175. htm] acessed Jan 2009

C25] B. Orphelin, M. Brum-Bousquet, F. Tillequim, M. Koch, C. Moretti, Heterocycles 43 (1) (1996) 173. Universidade Estadual do Norte Fluminense Darcy Ribeiro, 2007. URL [http:/www dominiopublico gov Takeya, H. Itokawa, Chem. Pharm. Bull. 40(11) (1992) 2970. [21] A.F. Magalhães, A.M.G.A. Tozzi, C.C. Santos, E.G. allemão: isolamento, determinação estrutural e atividade
[26] C. Borel, M.P. Gupta, K. Hostettmann, Phytochemistry 26 (1987) 2685

27 M. S. Abdel-Kader, B. D. Bahler, S. Malone, M. C. M. Werkhoven, J. H. Wisse, K. M. Neddermann, I.Bursuker, D. G. I. Kingston, J. Nat. Prod. 63(11) (2000) 1461

[28] A. F., Magalhães A.M.G.A. Tozzi, C.C. Santos, E.G. Magalhães, D. R. Serrano, E. M. Zanotti-Magalhães, E. G. Magalhães, Mem. Inst. Oswaldo Cruz 98(5) (2003) 713. [29] V. Angyalossy-Alfonso, R. B. Miller, IAWA J. 23(4) (2002) 359 